Landslides (2013) 10:315-322 DOI 10.1007/s10346-012-0377-x Received: 9 July 2012

Accepted: 2 December 2012

Published online: 6 January 2013

(c) The Author(s) 2013. This article is published with open access at Springerlink.com
D. P. van Zeyl · L. A. Penner · R. A. Halim

\section{A slope failure caused by drainage cutoff through the advancement of seasonal frost, Hudson Bay Lowland}

Abstract A failure occurred between December 14 and 17, 2008 in the upper part of a $45-\mathrm{m}$ high, northwest facing bank of the Nelson River in northern Manitoba $\left(56.687^{\circ} \mathrm{N}, 93.777^{\circ} \mathrm{W}\right)$. The slope failure occurred at a spring site in a bay associated with a buried valley. The sediment input to the river from this event is roughly 20,000 to $25,000 \mathrm{~m}^{3}$. The source zone is made up of $25 \mathrm{~m}$ of water-bearing sand and gravel confined between ice-rich silty clay at the top of the bank and laminated to rhythmically bedded silt and clay at the base of the section. The collapse was confined to the material above the basal silts and clays and was associated with a perched groundwater flow system. A strong argument for drainage cutoff by the advancement of seasonal frost has been demonstrated through the correlation of the bank collapse with the timing of a significant cold snap recorded at two nearby weather stations. The failure illustrates the importance of stratigraphy in controlling bank erosion in this area. Previously, fluvial erosion was seen as an important control on mass wasting in Horseshoe Bay. However, surface information suggests that no toe erosion except to remove the slide deposit has occurred at this site since 2004 .

Keywords Frost penetration - Layered slope - Perched aquifer · Bank erosion · Hudson Bay Lowland · Subarctic climate

\section{Introduction}

A significant volume of sediment was delivered into the Nelson River by a bank failure that occurred in December 2008, about $90 \mathrm{~km}$ inland of Hudson Bay (Figs. 1 and 2). The failure appears to have been caused by the advance of seasonal frost during a cold snap, a mechanism not often described in the literature but that should be expected in certain geological settings in northern regions. The landslide was studied during an erosion assessment for the potential Conawapa hydropower project being planned by Manitoba Hydro. The failure occurred $1 \mathrm{~km}$ downstream of the potential generating station and represents the single largest erosional event observed in the area during erosion studies to date. By providing a record of the failure mechanism and failure zone stratigraphy, this case record illustrates the importance of stratigraphy in controlling bank erosion in the area.

Bank erosion in this area can result in ecological impacts associated with loss of riparian habitat, disturbance to fisheries through increased turbidity, and the destruction of heritage resources. In addition to generating potentially destructive waves, sediment delivered by landslides into hydroelectric reservoirs can reduce reservoir capacity.

\section{Previous work}

During reconnaissance work from Split Lake to Hudson Bay, Piteau (1972) found that actively failing slopes were a common feature along the banks of the Nelson River. Dredge and Nielsen (1985) described bank failures along the Nelson estuary. Upstream of Horseshoe Bay,
Donnelly et al. (1990) described minor mudslides initiating from water-bearing, granular deposits near the top of the bank, and they documented a failure mechanism involving creep-like deformation at the base of a till bank related to a weak varved clay deposit. Penner et al. (1975) provided descriptions and interpretations of mass wasting processes in their work on the Nelson River. Shallow flows and slides in ice-rich colluvium are common where forest fires have altered the insulative properties of the organic mat. Dredge and Nixon (1992) suggested that low ice contents at depth were responsible for the absence of massive permafrost-related slope failures along the rivers in this area.

Unpublished limit equilibrium stability analysis of the December 2008 landslide was presented informally in May 2010 as part of ongoing work associated with the potential Conawapa Generating Station. The stability analysis relied on the only nearby borehole to establish the near-bank stratigraphy, which resulted in the assumption that the entire bank was composed of sands. The investigation identified a need to explain the occurrence of the landslide during open water conditions, as open water conditions were favourable compared with other scenarios considered in the stability analysis (e.g., rapid drawdown).

\section{Data sources}

Field observations were made at Horseshoe Bay on October 11, 2010. The section of bank about $50 \mathrm{~m}$ upstream of the December 2008 landslide was visited (Fig. 3 a). Recent erosion at this site had produced a clear exposure of the stratigraphy in the upper part of the bank.

Several information sources were reviewed for this site investigation. This includes available maps and reports, low-level oblique aerial photos, vertical air photos $(1985,1993,2003$, and 2006), borehole data, and an integrated SONAR and LiDAR digital elevation model. Climate and water level data were reviewed in order to assess the triggering mechanism. The nearest weather station (Fig. 1) with continuous coverage from 1971 is the Gillam Airport station (Environment Canada 2012). In addition, Manitoba Hydro records weather and water level data at a station about $500 \mathrm{~m}$ upstream of Horseshoe Bay at Axis B (Fig. 2). A 2011 survey transect was used to estimate the volume of the landslide through comparison with a profile taken from the 2004 LiDAR surface.

\section{Physical setting}

\section{Geology}

The study area is located (Fig. 1) within the Hudson Bay Lowland (Bostock 1970), which is a low lying plain where the primary relief components are major river valleys that have cut through Quaternary deposits 60 or more metres thick and have incised a much shorter depth into the underlying Paleozoic carbonate bedrock. The banks of the Nelson River locally expose a Pleistocene sequence of up to four till units and two interglacial units (Roy 1998; Nielsen and Dredge 1982, 1987; Nielsen et al. 1986; Dredge and McMartin 2011). The fine- 


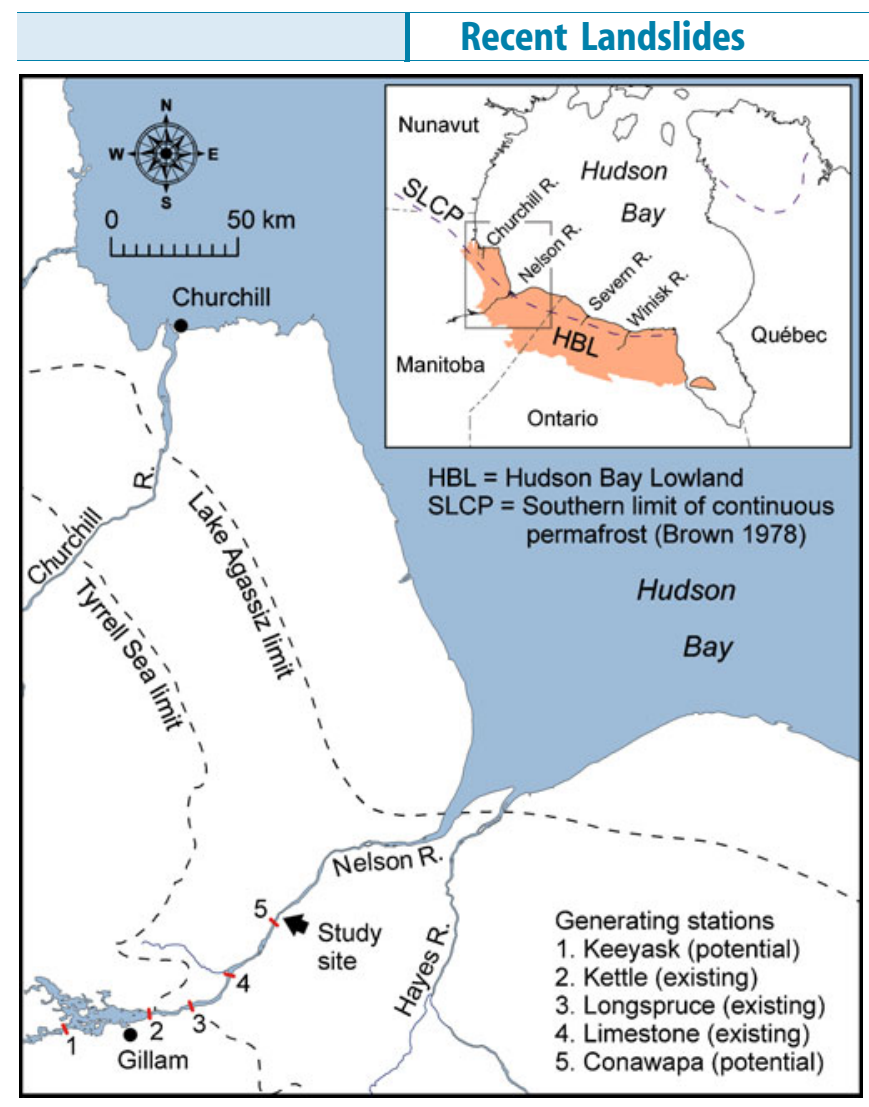

Fig. 1 Location of the study site in northern Manitoba. Lake Agassiz and Tyrrell Sea limits after Teller et al. (1983)

grained postglacial Lake Agassiz and Tyrrell Sea sediments capping many of the banks in the area represent the principle ice-rich inorganic materials exposed along the Nelson River (Johnston 1969; Peters and McKeown 1976; Piteau 1972). Poor drainage conditions imparted by the ice-rich, fine-grained, flat-lying postglacial deposits play an important role in rendering the Hudson Bay Lowland one of the largest wetlands in the world (Zoltai 1973).

Horseshoe Bay is a location where postglacial granular deposits within a buried valley are exposed in the south bank of the Nelson River. Exploratory drilling in the 1960 s revealed the presence of nearby ancient channels possibly associated with the buried valley exposed at Horseshoe Bay. One of the channels, termed the South trough (Fig. 2), is located beneath the bed of the Nelson River. Drilling has shown that this buried channel exceeds depths of 10 to $15 \mathrm{~m}$ below sea level, cutting through calcitic dolostone and dolomitic limestone of the Ordovician Bad Cache Rapids Group. The other channel is expressed as a topographic low on the upland southeast of the river (Fig. 2).

\section{Climate}

The climate of the area is humid subarctic and consists of cool, short summers and long, cold winters. The study area is located near the southern boundary of the continuous permafrost zone (Fig. 1) and the northern limit of the boreal forest (Dredge 1992). Excluding alpine permafrost, the Hudson Bay Lowland features the most southerly continuous permafrost found in Canada (Brown 1978), reflecting the cooling influence of Hudson Bay. Rouse (1991) showed that summer maritime cooling is most strongly developed in the part of the Hudson Bay Lowland near the Nelson estuary.

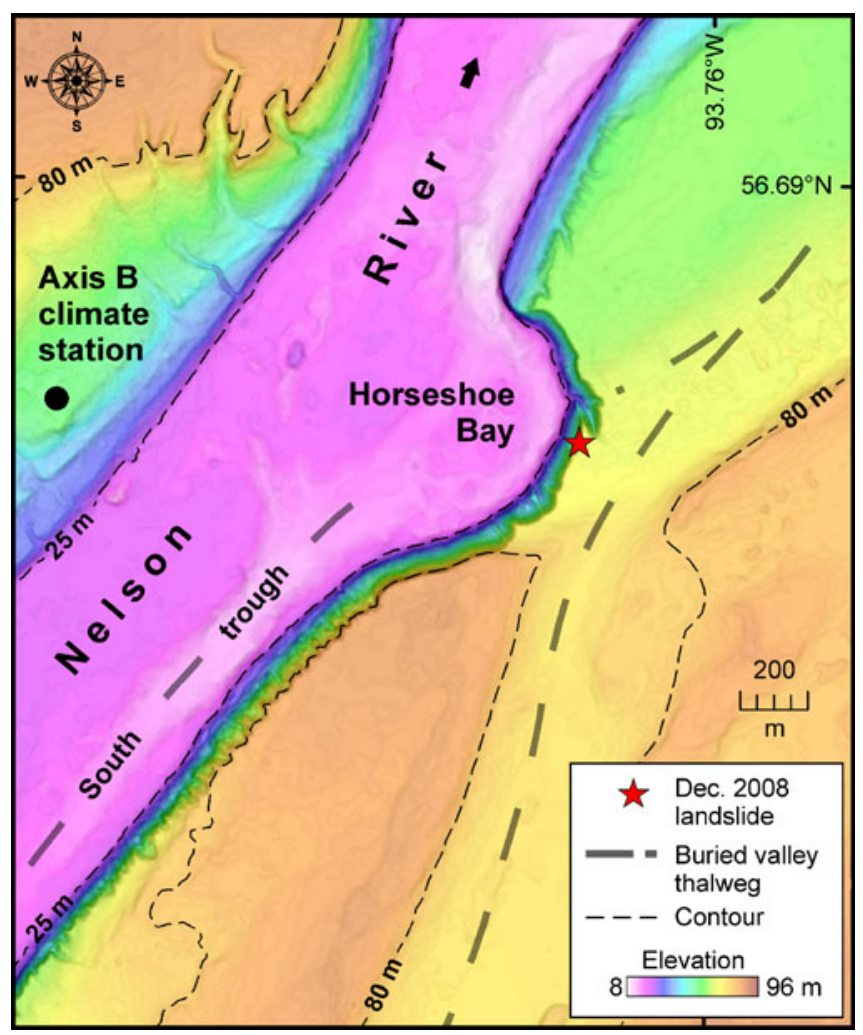

Fig. 2 Combined LiDAR and SONAR elevation model (metres above sea level) showing location of Horseshoe Bay on the Nelson River. Weather and water level data are collected at the location indicated as the "Axis B climate station"

\section{Hydrology}

The Nelson River is the single largest contributor of freshwater to Hudson Bay and James Bay (Déry et al. 2011). The Nelson River downstream of Gillam is a heavily entrenched channel with typical widths of 500 to $1,500 \mathrm{~m}$. The channel is dominantly straight with occasional bends. Discharge has been recorded at the Limestone Generating Station since 1990, with peak flows in July and August of 5,000 to $6,000 \mathrm{~m}^{3} / \mathrm{s}$.

The formation of river ice up to $10 \mathrm{~m}$ thick can facilitate bank erosion in this area, particularly through increasing water levels. Water levels near Horseshoe Bay are at about $25 \mathrm{~m}$ elevation during open water conditions. During this time, water level fluctuation is less than 1.0 to $2.0 \mathrm{~m}$ despite the occurrence of summer peak flows. In contrast, water levels can reach elevations of 35 to $38 \mathrm{~m}$ or more during winter staging. This can raise water levels above armoured or bedrock shorelines into weaker bank materials that are then subject to wetting, increased pore pressures and exposure to ice scour and plucking (Prowse and Culp 2003). Ice destaging can result in bank failures caused by rapid drawdown.

\section{Failure zone stratigraphy}

Cross section A-A' provides a simple outline based on available borehole data of the interpreted geometry of the postglacial, glacial and preglacial deposits overlying Ordovician bedrock in Horseshoe Bay (Fig. 4). The three postglacial units shown near the bank in this drawing are drawn based on the section observed in the field near the site of the December 2008 landslide. Each unit is described in the following subsections. 

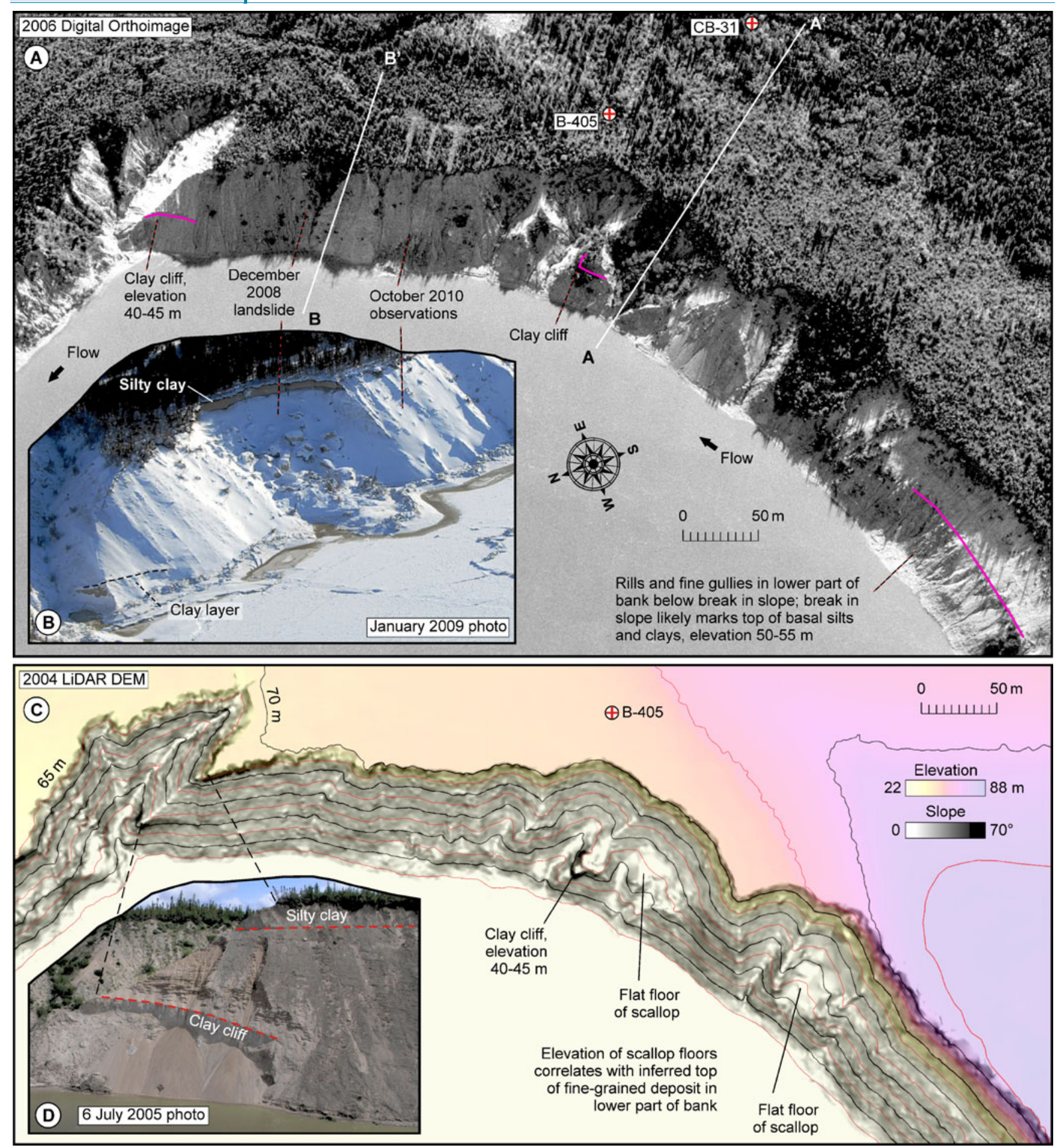

Fig. 3 Aerial orthoimage (a) and LiDAR image (c) of Horseshoe Bay, with inset photo of December 2008 landslide (b) and photo illustrating bank stratigraphy immediately downstream (d). Pink lines (a) indicate inferred upper contacts of basal silts and clays

\section{Frozen silty clay}

The top of the bank at Horseshoe Bay is capped by a 2.5-m thick light brown to greenish-grey brown, horizontally bedded, frozen, partly oxidized silty clay unit containing trace gravel comprising dominantly pebbles with occasional cobbles and boulders. The lowest $10 \mathrm{~cm}$ of the unit is fossil-rich and appears to contain a relative abundance of gravel. This unit contained visible ice in the form of discontinuous veins of ice up to $6 \mathrm{~mm}$ thick with a tendency towards orientations roughly parallel and perpendicular to bedding.

Klassen (1986) indicates that Tyrrell Sea sediments consist of clay, silt, sand and gravel. They are commonly fossiliferous and typically range in thickness from 1.2 and $3 \mathrm{~m}$, but can reach thicknesses of $30 \mathrm{~m}$. Thus, it is likely that the frozen sediment 


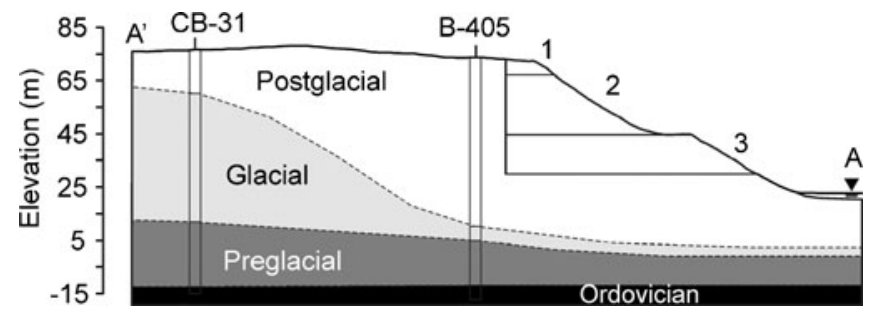

Fig. 4 Cross section A-A' showing outline of postglacial, glacial (silty clay till) and preglacial (sand and gravel) deposits inferred from borehole data. Postglacial units based on field and LiDAR data ( 1 frozen silty clay, 2 sands and gravel, 3 basal silts and clays)

capping the sequence at Horseshoe Bay represents marine deposits formed when the Tyrrell Sea inundated the isostatically depressed Hudson Bay Lowland following final deglaciation.

The most significant ground ice occurrence reported to date in the Conawapa area was from a borehole (B-411) located on the upland about $2 \mathrm{~km}$ south of Horseshoe Bay. Ice inclusions up to $30 \mathrm{~cm}$ thick were recorded within a $9-\mathrm{m}$ thick grey silty clay beneath $5 \mathrm{~m}$ of frozen peat. Moisture contents up to $87 \%$ were recorded in the most ice-rich zone. The lowest $40 \mathrm{~cm}$ of the silty clay unit contained a relative abundance of sand and gravel. This silty clay formation likely correlates with the frozen silty clay unit observed at Horseshoe Bay and described above.

\section{Sands and gravels}

Granular material observed in the section was confined to a lower light-brown-coloured sand unit beneath a brown sand and gravel unit. The lower sand unit comprises dominantly loose, well sorted, cross-stratified medium-grained sand with some undulating clay layers 1 to $5 \mathrm{~cm}$ thick. White shells were observed in the lower sand unit, possibly indicating marine deposition. The upper unit consists of loose, cross-stratified sand and gravel beds up to about $30 \mathrm{~cm}$ thick.

\section{Basal silts and clays}

At about 40 m elevation, the top of a laminated clay unit was clearly exposed. This clay deposit displays dominantly grey, low amplitude, undulating, millimetre-scale laminae. An exposure of rhythmically bedded clay was also observed. The beds are planar and about $8 \mathrm{~cm}$ thick. Each bed is grey with a planar black clay horizon up to about $0.5 \mathrm{~cm}$ thick marking the transition to the next bed.

In addition to the field observations described above, the LiDAR image and aerial photos display clay cliffs and a break in slope indicative of the top of a similar aquitard in other sections of Horseshoe Bay (Fig. 3). The features are at about 50 to $55 \mathrm{~m}$ elevation in the upstream part of Horseshoe Bay and 40 to $45 \mathrm{~m}$ elevation near the December 2008 landslide (Fig. 3a).

December 2008 landslide

\section{Slide deposit}

The slide deposit was first identified on December 17, 2008, and the first photographs of it were obtained in January 2009. The deposit shown in the January 2009 photo (Fig. 3b) consists of a lobe extending from the lower part of the bank. It is impossible to see the lowest extent of the landslide deposit in the January 2009 photo because water levels in the photo reflect 8 to $10 \mathrm{~m}$ of staging above the normal open water shoreline.

Photos of the landslide taken in summer 2009 show a flat zone above the shoreline (Fig. 5), which is also shown in the 2011 transect survey (Fig. 6). This flat zone coincides with the top of the basal silts and clays, and it is clear that the failure was restricted to the material above this zone. Similarly, the floors of other scallop-shaped erosional landforms in Horseshoe Bay are coincident with the top of the basal silts and clays, suggesting that much of the mass wasting here has been related to erosion in the granular material overlying the basal silts and clays.

The volume of the December 2008 landslide was estimated by comparing a survey line taken in 2011 with a profile taken from the 2004 LiDAR surface (Fig. 6). As the survey line does not extend through the centre of the slide, the area between the profiles would be larger for profiles through the centre and smaller for profiles near the margins. With an estimated slide width of $50 \mathrm{~m}$ and an assumed average sectional area of 400 to $500 \mathrm{~m}^{2}$, the volume of sediment input to the river would be roughly 20,000 to $25,000 \mathrm{~m}^{3}$.

Comparison of the 2004 and 2011 profiles (Fig. 6) shows remarkably little change in the position of the bank below about $40 \mathrm{~m}$ elevation. The only noticeable change is a small accumulation at the toe of the slope. It is not known with certainty whether toe erosion occurred in the intervening period, but the remarkable match between 2004 and 2011 profiles suggests that there has been no appreciable fluvial erosion into the bank since 2004 other than to remove the slide deposit. This is consistent with the notion that fluvial erosion did not trigger the December 2008 landslide. This finding is significant because previously toe erosion was seen as an important mechanism causing mass wasting in Horseshoe Bay.

\section{Triggering mechanism}

Water levels leading up to the occurrence of the landslide were normal for open water conditions, and winter staging did not begin for more than 20 days after the bank failure. Thus, the occurrence of the landslide did not correlate with an abnormal change in water level or with events related to winter staging.

Another explanation is that drainage of the slope was impeded by a frost barrier formed beneath the seepage face. Tart (1996) suggests that this slope failure mechanism is common in northern regions. This hypothesis was first tested by examining daily temperature data from the Gillam and Axis B weather stations. Temperature data from the two stations correlated strongly and revealed an abrupt and sustained drop in temperature representing an almost $2.0^{\circ} \mathrm{C}$ average drop per day over 15 days (Fig. 7). This was followed by 5 to 8 days with average daily temperatures less than $-28{ }^{\circ} \mathrm{C}$ leading up to the occurrence of the landslide between December 14 to $17,2008$.

A further test of this hypothesis was to evaluate whether the temperature drop observed in December 2008 was abnormal. For this, October through December daily average temperature data were plotted for the years 1985 through 2011 (Fig. 8). Several years showed temperature declines to extreme low values that were more abrupt than that recorded in 2008, but in each of these years, the temperatures rose shortly after plummeting. As a result, the 2008 cold snap stands out graphically as a significant cold snap.

Snow depth is an important factor to consider in any analysis of frost penetration. According to Goodrich (1982), the depth of seasonal frost is extremely sensitive to details of the snow cover 


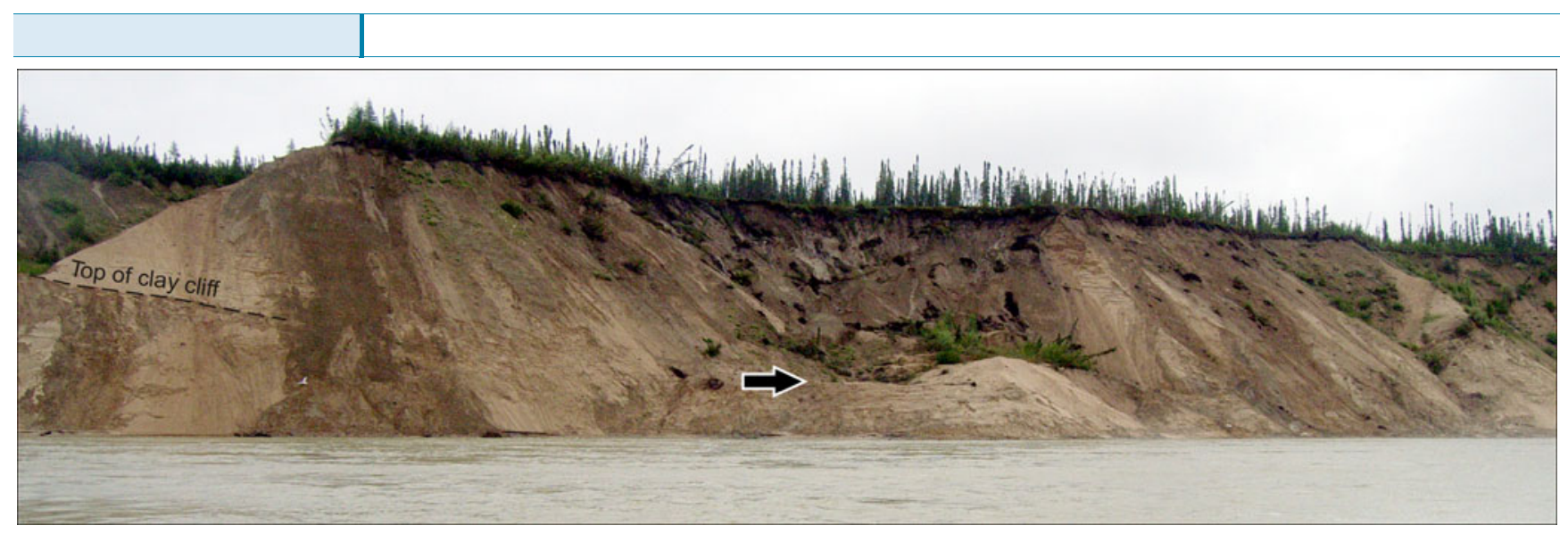

Fig. 5 Photo of the December 2008 landslide taken on July 15, 2009. Arrow indicates flat zone interpreted to coincide with the top of the basal silts and clays and the base of the December 2008 landslide

build-up, such that autumn penetration can represent a significant amount of the annual frost depth achieved. A heavy snowfall in the autumn will inhibit winter frost penetration (Brown 1970). Unfortunately, snow depth measurements at the landslide site do not exist. Snow accumulation on the riverbank would be a function of snowfall, air temperature, vegetation and the interaction between wind and detailed topographic irregularities.

In the absence of local snow depth data, a simple statistic that could be used to rank the severity of a cold snap in such a way as to indirectly account for the snow depth and air temperature conditions required to maximize frost penetration is the absolute range in average monthly temperature observed between October and December. Above average temperature in October and November could prevent a heavy autumn snow accumulation. Ranked in terms of this statistic, the top three cold snaps for the period 1971 to 2011 at Gillam occurred in $2008\left(29.6{ }^{\circ} \mathrm{C}\right), 1984\left(29.3^{\circ} \mathrm{C}\right)$ and $2000\left(29.0^{\circ} \mathrm{C}\right)$. This further emphasizes the significance of the 2008 cold snap for its frost penetration potential.

\section{Discussion}

The volume of the December 2008 landslide is estimated as roughly 20,000 to $25,000 \mathrm{~m}^{3}$. Given that Penner et al. (1975) estimated the volume of sediment input to the $145 \mathrm{~km}$ long reach of the Nelson River downstream of the Kettle Generating Station (Fig. 1) by bank erosion to be approximately $120,000 \mathrm{~m}^{3}$ per year, it is clear that the December 2008 landslide represents a significant erosional event.

\section{Climatic controls}

Prior to the current study, a preliminary investigation of the December 2008 landslide identified a need to explain the occurrence of the failure during open water conditions, as the stability analysis suggested that

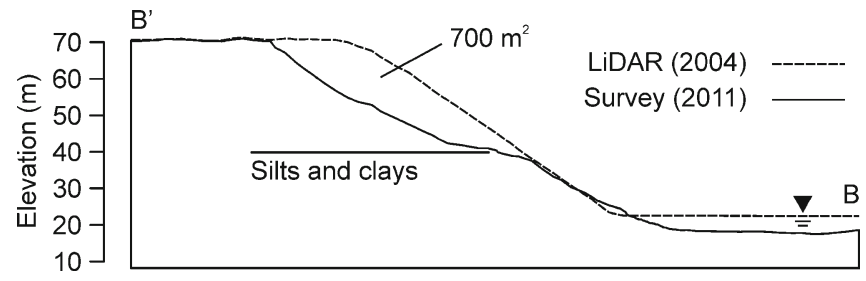

Fig. 6 Cross section B-B' showing profiles from summer 2011 and September 2004 open water conditions were favourable compared with those during winter staging and during rapid drawdown during ice destaging.

The current study found that the timing of the December 2008 landslide coincided with a significant cold snap. This supported the notion that the landslide was caused when frozen ground near the face of the bank formed an effective barrier against groundwater flow thereby forcing the groundwater level to rise behind the freeze front until a sufficient hydraulic head developed to cause the barrier and the slope above to collapse. This failure mechanism, which Tart (1996) indicates is a common mode of failure in cold climates, provides a likely explanation for the timing of the instability.

In addition to the extreme low air temperatures reached during winter in this region, the groundwater is generally colder than what is common in southern Manitoba where typical groundwater temperatures in unurbanized areas are in the order of 4 to $6{ }^{\circ} \mathrm{C}$ (Render 1970; Ferguson 2004). Thermal well readings from boreholes within the Conawapa project area indicate typical groundwater temperatures of 1 to $2{ }^{\circ} \mathrm{C}$ (Power, 2011). As a result, for a given air temperature, the colder groundwater in this area will freeze sooner.

The northwest aspect of the bank is another factor that would render the site of the December 2008 landslide susceptible to frost penetration. Northerly aspects would receive a reduced amount of insolation as compared with a south facing bank (Harlan and Nixon, 1978).

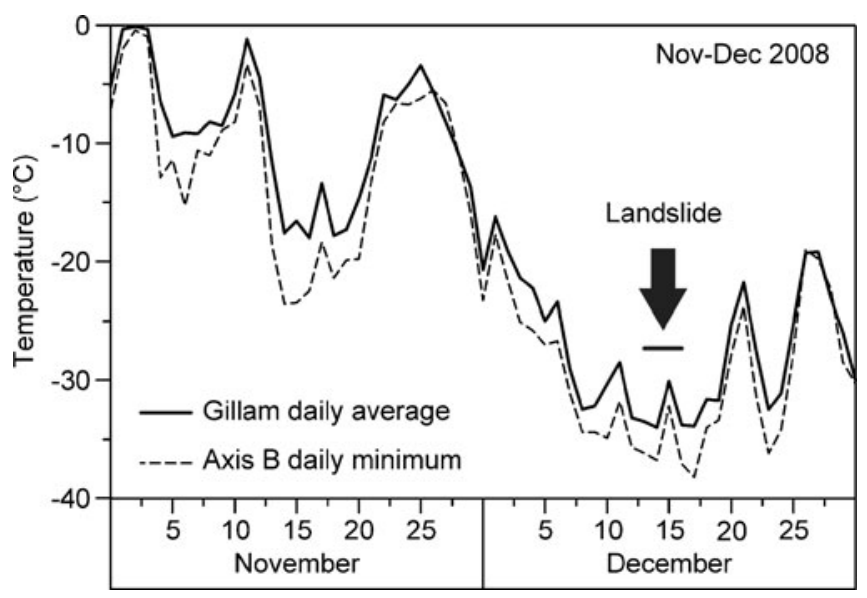

Fig. 7 Fall-winter daily mean air temperatures at Gillam and Axis B 

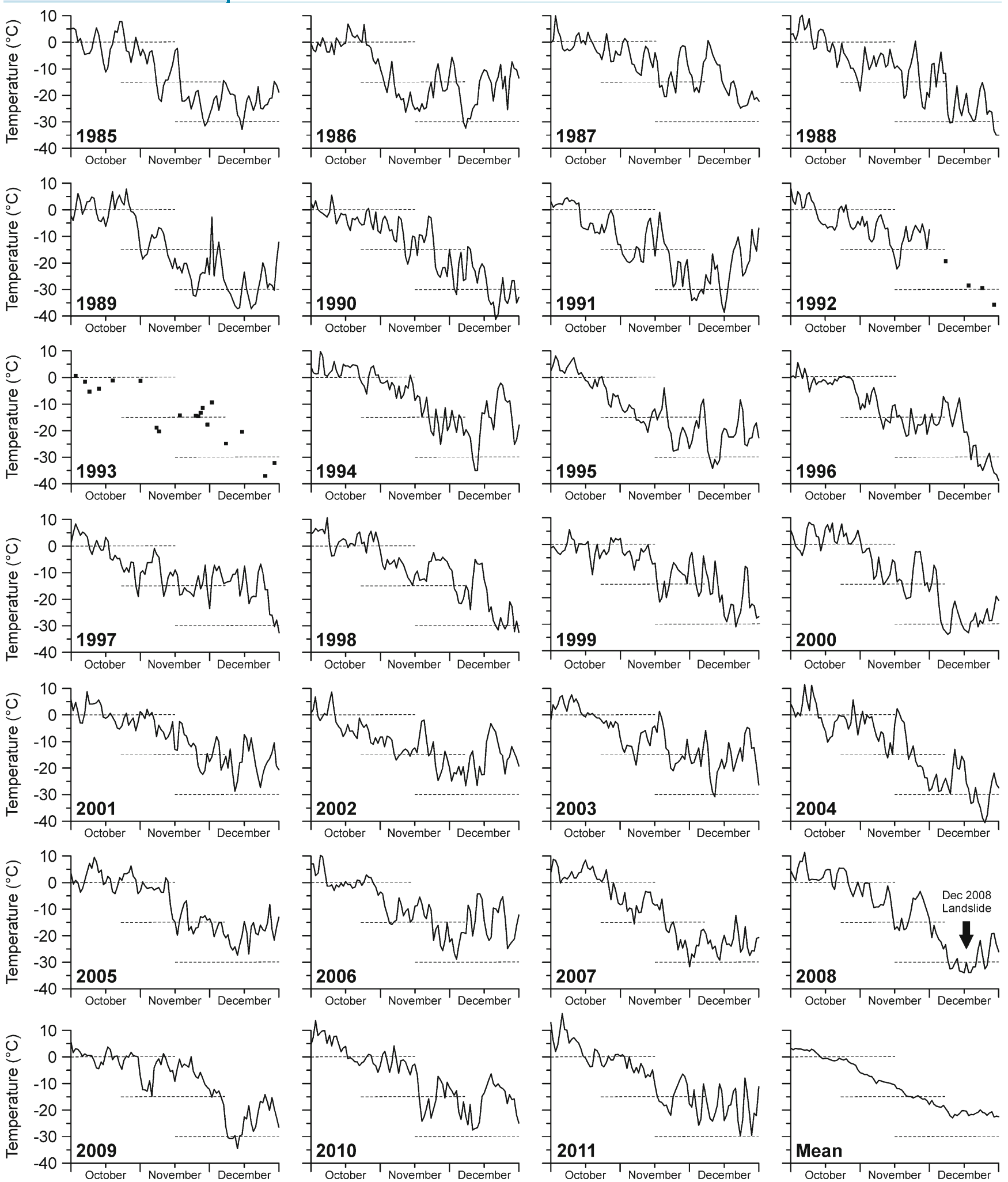

Fig. 8 Fall-Winter daily mean air temperatures at Gillam 1985-2011

The melting of permafrost appears to have played no role in facilitating the December 2008 landslide. It is suspected that the stiffness of the frozen silty clay at the top of the bank was responsible for restricting the mobility of the frozen silty clay and the peat and forest cover. It is assumed that if sand extended to the top of the bank, then the volume of 
sediment and organic material input to the river would have been larger.

\section{Geological controls}

This study provided a preliminary description of the geological setting of the December 2008 landslide. The three stratigraphic units described consist of a $20 \mathrm{~m}$ thick unit of sands and gravels confined between frozen silty clays above and laminated to rhythmically bedded silts and clays below.

Prior to the current study, the preliminary investigation of the December 2008 Horseshoe Bay landslide relied on borehole B-405 to establish the near-bank portion of the geological section used for stability analysis. Despite its proximity to the valley edge where field observations were made in October 2010, the log for B-405 did not report the silty clay found at the top of the bank or the silts and clays observed at the bottom of the bank. It records dominantly moist, brown sand interbedded with occasional minor layers of silty clay, silt or gravel for the height of the bank. As such, the near-bank geology assumed in the stability model did not include any layers of low permeability. This explains the contradiction between model results and the observation that the failure occurred during open water conditions, as the pore pressure field from a homogeneous analysis is likely to be significantly in error when applied to stability analysis in layered slopes (Hodge and Freeze 1977; Rulon and Freeze 1985).

The reason why B-405 did not intersect the basal silt and clay is probably related to the complex geometry of deposits within the buried valley. As sonic drilling was used, which generally produces excellent core samples, it is difficult to conceive that the core logger could have missed the silt and clay formation observed in the lower part of the banks in Horseshoe Bay. In any case, the borehole does not provide an accurate image of the stratigraphy at the landslide site. This illustrates the value that fieldwork, topographic analysis and photo interpretation by skilled practitioners can add to slope investigations.

The presence of an aquitard in the lower part of a bank often results in a perched aquifer (Sterrett and Edil 1982). In the case of Horseshoe Bay, the basal silt and clay formation promotes failure in the overlying porous material. Examples of other types of failures that can occur in this type of geological setting are often classified in the literature as slope instabilities induced by seepage erosion (Hutchinson 1968, 1988; Dunne 1990; Crosta and di Prisco 1999). The findings presented here illustrate the important role that alternating layers of high and low permeability can have on controlling the extent and mechanism of failure.

\section{Summary}

The timing of the December 2008 Horseshoe Bay landslide coincided with a significant cold snap recorded at two nearby weather stations. This and the observed stratigraphic setting strongly support the notion that the failure was caused by drainage obstruction through the temporary formation of a frost barrier. The failure was not caused by winter staging or destaging, permafrost melting or open water toe erosion. As the only ice-rich unit encountered at the landslide site was the marine silty clay at the top of the bank, permafrost had little influence on the landslide. This study suggested that, except to remove the landslide debris, no toe erosion has occurred at this site since 2004. The extent and mechanism of failure were strongly controlled by groundwater flow and the presence of an aquitard in the lower part of the bank.

Acknowledgments

Thoughtful early reviews of the manuscript were provided by Peter J. Barnett (Ontario Geological Survey), Marc-André Brideau (University of Auckland) and Jason Mann (KGS Acres Ltd.). Two anonymous reviewers made suggestions that greatly improved the presentation. Howard Beardy of the Fox Lake Cree Nation assisted with the October 2010 fieldwork. Mike Morris (Manitoba Hydro), Jeff Krut (KGS Acres Ltd.) and Peter Hillius (Manitoba Hydro), respectively, provided Conawapa climate data, water level data and digital copies of early engineering reports. Ninel Gonzalez (Manitoba Hydro) provided the 2011 survey data used for the volume estimate. Special thanks go to Paul Dubreuil and staff at the Conawapa Camp for facilitating the October 2010 field visit. The authors wish to thank Manitoba Hydro for granting permission to publish this work.

Open Access This article is distributed under the terms of the Creative Commons Attribution License which permits any use, distribution, and reproduction in any medium, provided the original author(s) and the source are credited.

\section{References}

Bostock HS (1970) Physiographic regions of Canada. Geological Survey of Canada, Map $1254 \mathrm{~A}$

Brown RJE (1970) Permafrost in Canada: its influence on northern development. University of Toronto Press, Toronto

Brown RJE (1978) Permafrost. Plate 32 in hydrological atlas of Canada. Canadian National Committee for the International Hydrological Decade, Ottawa

Crosta G, di Prisco C (1999) On slope instability induced by seepage erosion. Can Geotech J 36(6):1056-1073

Déry SJ, Mlynowski TJ, Hernández-Henríquez MA, Straneo F (2011) Interannual variability and interdecadal trends in Hudson Bay streamflow. J Mar Syst 88(3):341-351

Donnelly CR, Osiowy KB, Kilgour DA (1990) Conawapa Generating Station 1989 summer exploration program south abutment results. Report submitted by Crippen Acres Limited and Wardrop Engineering Inc. to Manitoba Hydro, H10003.19.04, No. 0019211600, 14 December 1990.

Dredge LA (1992) Field guide to the Churchill Region, Manitoba, Glaciations, sea level changes, permafrost landforms, and archaeology of the Churchill and Gillam areas. Geological Survey of Canada, Miscellaneous Report 53, p 52

Dredge LA, McMartin I (2011) Glacial stratigraphy of northern and central Manitoba. Geological Survey of Canada, Bulletin 600, p 27

Dredge LA, Nielsen E (1985) Glacial and interglacial deposits in the Hudson Bay lowlands: a summary of sites in Manitoba. Geological Survey of Canada, Current Research, Part A, Paper 85-01A, pp 247-257

Dredge LA, Nixon FM (1992) Glacial and environmental geology of northeastern Manitoba. Geological Survey of Canada, Memoir 432, p 66

Dunne T (1990) Hydrology, mechanics, and geomorphic implications of erosion by subsurface flow. In: Higgins CG, Coates DR (eds), Groundwater geomorphology; The role of subsurface water in earth-surface processes and landforms. Geological Society of America, Special Paper 252, pp 1-28

Environment Canada (2012) National Climate Data and Information Archive. Data for GILLAM A. http://climate.weatheroffice.gc.ca/climateData/canada_e.html. Accessed 04 Feb 2012

Ferguson GAG (2004) Groundwater and heat flow in southeastern Manitoba: implications to water supply and thermal energy. Ph.D. thesis, University of Manitoba, Winnipeg, p 425

Goodrich LE (1982) The influence of snow cover on the ground thermal regime. Can Geotech J 19:421-432

Harlan RL, Nixon JF (1978) Ground thermal regime. In: Andersland OB, Anderson DM (eds) Geotechnical engineering for cold regions. McGraw-Hill, New York, pp 103-163 


\section{Recent Landslides}

Hodge RAL, Freeze RA (1977) Groundwater flow systems and slope stability. Can Geotech J 14(4):466-476

Hutchinson JN (1968) Mass movement. In: Fairbridge RW (ed) The encyclopedia of geomorphology. Reinhold, New York, pp 688-695

Hutchinson JN (1988) General report: morphological and geotechnical parameters of landslides in relation to geology and hydrogeology. In: Bonnard C (ed) Proceedings, Fifth International Symposium on Landslides, A.A. Balkema, Rotterdam, pp 3-36

Johnston GH (1969) Dykes on permafrost, Kelsey Generating Station, Manitoba. Can Geotech J 6:139-157

Klassen RW (1986) Surficial geology of north-central Manitoba. Geological Survey of Canada, Memoir 419, p 57

Nielsen E, Dredge LA (1982) Quaternary stratigraphy and geomorphology of a part of the lower Nelson River. Geological Association of Canada, Winnipeg Section, Manitoba

Nielsen E, Dredge LA (1987) Manitoba - The Churchill and Gillam Areas. In: Schreiner BT, Dredge LA, Nielsen E, Klassen RW, Fenton MM, Vickers JR, XII ${ }^{\text {th }}$ INQUA Congress Field Excursion C-13, The Quaternary between Hudson Bay and the Rocky Mountains, July 1987, pp 7-23

Nielsen E, Morgan AV, Morgan A, Mott RJ, Rutter NW, Causse C (1986) Stratigraphy, paleoecology, and glacial history of the Gillam area, Manitoba. Can J Earth Sci 23:1641-1661

Penner F, Sie D, Henderson H, Ould P (1975) Lower Nelson River Study, river geomorphology and timber clearing. Water Resources Branch, Manitoba Department of Mines, Resources and Environmental Management, March 1975, p 276

Peters J, McKeown J (1976) Glacial till and the development of the Nelson River. In: Leggett RF (ed) Glacial till. Royal Society of Canada, Special Publication no. 12, Ottawa, pp 364-380

Piteau DR (1972) Engineering geology aspects relating to preliminary damsite investigations on the Nelson River, Manitoba. Can Geotech J 9:304-313

Power AB (2011) 2010 Conawapa Monitoring Report Instrument Monitoring and Sampling. Manitoba Hydro Report ESD11-31, p 728

Prowse TD, Culp JM (2003) Ice breakup: a neglected factor in river ecology. Can J Civ Eng 30(1):128-144
Render FW (1970) Geohydrology of the metropolitan Winnipeg area as related to groundwater supply and construction. Can Geotech J 7:243-274

Rouse WR (1991) Impacts of Hudson Bay on the terrestrial climate of the Hudson Bay Lowlands. Arct Alp Res 23(1):24-30

Roy M (1998) Pleistocene stratigraphy of the lower Nelson River area - Implications for the evolution of the Hudson Bay Lowland of Manitoba, Canada. M.Sc. thesis, Université du Québec à Montreal, Montreal, Quebec, p 220

Rulon JJ, Freeze RA (1985) Multiple seepage faces on layered slopes and their implications for slope-stability analysis. Can Geotech J 22(3):347-356

Sterrett RJ, Edil TB (1982) Ground-water flow systems and stability of a slope. Ground Water 20(1):5-11

Tart RG Jr (1996) Chapter 25: Permafrost. In: Turner AK, Schuster RL (eds) Landslides: investigation and mitigation. Transportation Research Board, Special Report 247, National Research Council, National Academy Press, Washington, D.C., pp $620-645$

Teller JT, Thorleifson LH, Dredge LA, Hobbs HC, Schreiner BT (1983) Maximum extent and major features of Lake Agassiz. Geological Association of Canada, Special Paper 26, scale 1:3,000,000.

Zoltai SC (1973) Vegetation, surficial deposits and permafrost relationships in the Hudson Bay Lowland. In: Proceedings of the symposium on the Physical Environment of the Hudson Bay Lowland, March 30-31, 1973. University of Guelph, Guelph, Canada, pp $17-34$

\section{P. van Zeyl $(\varangle) \cdot$ L. A. Penner}

J.D. Mollard and Associates (2010) Limited,

810 Avord Tower, 2002 Victoria Avenue, Regina, SK S4P OR7, Canada

e-mail: vanzeyl@jdmollard.com

\section{R. A. Halim}

KGS Acres Ltd.

500 Portage Avenue, Winnipeg, MB R3C 3X1, Canada 